\title{
Mateusz Gąsiorowski
}

Państwowa Wyższa Szkoła Zawodowa w Płocku

ORCID: 0000-0002-1699-8907

\section{Niemiecka filozofia prawa XX wieku wobec problemów konstytucjonalizmu, red. Lukasz Perlikowski, Kamil Jesiołowski, Fundacja Societas et Ius, Toruń 2018.}

$\mathrm{Na}$ początek chciałbym przytoczyć krótką historię sporu konstytucyjnego w Polsce, kontekst ten jest niejednokrotnie sygnalizowany w książce oraz przywoływany w dyskusji.Przyczynąobserwowanegow Polsceod 2015 r. kryzysu konstytucyjnego, był ,jeden z przepisów przejściowych uchwały o Trybunale Konstytucyjnym przyjętej w czerwcu 2015 - który umożliwił poprzedniej większości rządzącej wybór pięciu nowych sędziów TK”" Po wyborach w 2015 r. działania Sejmu VIII kadencji, jak i Prezydenta Andrzeja Dudy względem Trybunału Konstytucyjnego można określić mianem contra legem. Ówczesny impas konstytucyjny miał dwutorowy przebieg - „sejmowy”, który swoją legislacją niejako sparaliżował pracę TK wykazując jego nieregulaminowy skład oraz "prezydencki”, związany z niekonstytucyjnym działaniem Andrzeja Dudy, który nie przyjął ślubowania od

${ }^{1}$ M. Szuleka, M. Wolny, M. Szwed, Kryzys konstytucyjny w Polsce 2015-2016, Helsińska Fundacja Praw Człowieka, http://www.hfhr.pl/wp-content/ uploads/2016/09/HFPC-Kryzys-konstytucyjny-w-Polsce-2015-2016.pdf (dostęp: 31.12.2019). trzech sędziów, wybranych prawidłowo przez Sejm VII kadencji. Zważywszy na wątki podejmowane $\mathrm{w}$ recenzowanej pozycji na pierwszy plan wysuwa się problematyka pozycji ustrojowej Prezydenta RP.

Recenzowana pozycja, wydana przez Fundację Societas et Ius składa się z dwóch wykładów wygłoszonych podczas seminarium, których autorami są kolejno: prof. Jerzy Zajadło i prof. Adam Wielomski. Następnie ze stenogramu dyskusji, w której udział wzięli wyżej wymienieni profesorowie oraz: dr hab. Marcin Wiszowaty, dr Karol Dobrzeniecki, dr Lukasz Perlikowski, mgr Magdalena Ziętek-Wielomska i mgr Kamil Jesiołowski. Uzupełnieniem tej pracy zbiorowej są ponadto artykuły prof. Zajadło, prof. Wielomskiego i mgr Jesiołowskiego.

Pierwszy wykład, autorstwa prof. Jerzego Zajadło zatytułowany jest Filozofia prawa Carla Schmitta? Tytuł kończąc się znakiem zapytania, nadaje tekstowi charakteru dociekań, stanowi próbę odpowiedzi na pytanie - czy istnieje uniwersalna, spójna filozofia prawa niemieckiego uczo- 
nego? Conditio sine qua non dla odbioru ogółu myśli politycznej, prawnej i kulturowej Schmitta jest dla prof. Zajadło wzięcie pod uwagę aspektu realiów historycznych, w których tworzył omawiany przez niego autor. Podkreślono, iż o ile $\mathrm{z}$ koncepcji polityczno-ustrojowych, takich jak: pojęcie suwerena, polityczności, teorii stanu wyjątkowego, czy też decyzjonizmu można wykrystalizować pewne uniwersalia, „niezbrukane” nazizmem, o tyle koncepcje filozoficzno-prawne ${ }^{2}$ zawierają pewną nutę nazistowskiej retoryki oraz żargonu. Profesor Zajadło doszukując się miarodajnej koncepcji filozofii prawa C. Schmitta, opiera się przede wszystkim na pozycji, zatytułowanej $O$ trzech sposobach myślenia w nauce prawa ${ }^{3}$. Głównym wnioskiem badacza jest stwierdzenie, iż filozofia polityki oraz „zdawkowa, ogólna refleksja nad istotą prawa" Schmitta, ukierunkowana jest na stworzenie, istnienie i utrzymanie stabilnego porządku polityczno-prawnego, nie zaś na utrzymywaniu permanentnego stanu wyjątkowego. Związek między myślą polityczną, kulturową oraz prawną zobrazowany został dwoma infografikami, ukazującymi transdyscyplinarność głównych dzieł Carla Schmitta. Trudności w ogólnej charakterystyce filozofii prawa, przysparza swoista niespójność ideologiczna niemieckiego prawnika tj. hybryda decyzjonizmu (pozornie przez niego odrzuconego) $\mathrm{z}$ instytucjonalną teorią prawa, w której modyfikuje teoretyczne źródła tak, by wkomponować ją w nazistowską reto-

2 Opracowania, traktujące tę tematykę wydawane były w latach 1933-1936, po akcesji Schmitta do NSDAP.

${ }^{3}$ J. Zajadło, Schmitt, wyd. Arche, Sopot 2016. rykę. Jednakowoż clue wykładu, będące zarzewiem późniejszej dyskusji dotyczącej kryzysu konstytucyjnego w Polsce, stanowi odrzucony element normatywizmu. Prof. Zajadło wskazuje na nadzwyczajne uprawnienia Prezydenta - będącego dla Schmitta uosobieniem suwerena, gotowego na działania poza-konstytucyjne, w pewnych szczególnych okolicznościach. Słowem podsumowania, wykład stanowi swego rodzaju podstawę merytoryczną dla dalszych rozważań zawartych $\mathrm{w}$ recenzowanej pracy zbiorowej.

W kolejnej części zatytułowanej Zgon państwa liberalnego. Kryzys polityczny w Polsce w kategoriach polityczności Carla Schmitta, prof. Adam Wielomski rozwija wątki zapoczątkowane przez prof. Zajadło. Kluczowymi elementami tego wykładu jest Schmittowska krytyka ustroju liberalnego oraz próba odpowiedzi na pytanie - jak zachowałby się Niemiec w obecnej sytuacji w Polsce? Schmittowska dezaprobata liberalizmu znalazła swoje ujście w przytaczanej przez Wielomskiego pozycji pt. Pojęcie polityczności z 1927 r. Polski uczony wymienił osiem zarzutów, stawianych liberalizmowi przez Schmitta, jest to kolejno: fałszywa antropologia, prymat jednostki nad państwem, niemożność wykrzesania istoty polityczności tj. poczucia wrogości i nienawiści, abstrakcyjność humanitarnych ideologii, błędna teoria państwa prawa, panekonomizm, agnostycyzm oraz podatność na socjalistyczny zwrot polityczny. Punktem kulminacyjnym wykładu, będącym argumentem $\mathrm{w}$ sporze podczas dyskusji jest pojęcie polityczności. Ukonstytuowanie zewnętrznego wroga narodu jest dla Schmitta synonimem idealnego modelu polityki, zdolnego zmobilizować 
masy ludzkie do wielu wyrzeczeń z powodu konieczności walki $\mathrm{z}$ wrogiem zewnętrznym. W tym sensie, polityka nabiera znaczenia międzynarodowego, abstrahując od jej wewnątrzpaństwowych przymiotów. Przeciwstawiony temu modelowi jest stan faktyczny, w którym polityka tworzy się z wewnątrzpaństwowych sporów politycznych/klasowych. Wielomski, przykładem tym obnaża niejako Schmittowskie przywiązanie do nacjonalizmu. Doktryna ta stawia na najwyższym miejscy w hierarchii wartości - państwo. Schmitt postuluje, iż wychodzenie z problemami państwowymi na zewnątrz jest aktem antypaństwowym, zmierzającym w kierunku wojny domowej. Tak więc z punktu widzenia niemieckiego prawnika: podnoszenie przez polskich polityków spraw wewnętrznych na forum Parlamentu Europejskiego nosi znamiona antypolonizmu. Finalną refleksją Schmitta, podnoszoną przez Wielomskiego jest problematyka intensywności sporu politycznego. Sformułowano tezę, iż aby doprowadzić do przelewu krwi, walczących ze sobą antagonistycznych grup na obszarze jednego państwa, potrzebny jest element czynnika religijnego/mitu politycznego. Wielomski, przytoczył tutaj za Schmittem powód ukształtowania się włoskiego faszyzmu (mit antybolszewicki) i zadaje pytanie czy „zamach smoleński” lub „walka z kaczyzmem" nie są nowymi, polskimi mitami politycznym o zabarwieniu religijnym ${ }^{4}$.

Kolejno, część trzecia będą stenogramem dyskusji stanowi swoiste uzupełnienie podejmowanych wcześniej wątków do-

${ }^{4}$ Niemiecka filozofia prawa XX wieku wobec problemów konstytucjonalizmu, red. Ł. Perlikowski, K. Jesiołowski, Societas et Ius, Toruń 2018, s. 49. tyczących twórczości „naczelnego jurysty III Rzeszy" - Carla Schmitta. Charakter recenzji nie pozwala na podjęcie wszystkich wątków podjętych podczas dyskusji, w związku $\mathrm{z}$ tym dokonam subiektywnej selekcji tematów, które zostaną krótko omówione. Otóż dyskusja zaczyna się od polemiki prof. Zajadło z prof. Wielomskim odnośnie sposobu rozumienia ogółu myśli Carla Schmitta. Wielomski zaznacza, iż podział na Schmittowską myśl polityczną, kulturową i prawną, charakterystyczny dla badaczy polskich i anglosaskich, może skutkować niejako ucieczką pierwotnego sensu ideologii niemieckiego prawnika. Kolejno wyjaśniono motywacje, które doprowadziły Schmitta do wstąpienia w szeregi NSDAP. Podobnie jak wątek poprzedni, także ten został doprecyzowany przez prof. Wielomskiego, który uważa, iż akcesja Schmitta do partii nazistowskiej była pokłosiem „nocy długich noży”. Unaocznia również czytelnikowi, iż powszechna opinia, która utożsamia „noc długich noży” jedynie $\mathrm{z}$ aktami antysemickimi jest co do zasady błędna. Dalej znajdujemy próbę odpowiedzi na stawiane przez prof. Wielomskiego pytanie odnośnie potencjalnego zachowania Schmitta w kontekście współczesnej sytuacji politycznej w Polsce. Schmitt, pozostając przy stanowisku nacjonalistycznym, cytuje słowa Mussoliniego „partie przechodzą, państwo pozostaje"s. Ponadto, zobrazowano ponadprawną ideologię decyzjonimu, zgodnie z którą, „Prezydent B. Komorowski, będący rzeczywistym suwerenem mógłby doprowadzić do delegalizacji PiS przed wyborami parlamentarnymi w 2015 r.. Uczestnicy dyskusji,

${ }^{5}$ Ibidem, s. 59. 
powracają również $\mathrm{w}$ pewnym momencie do „nocy długich noży” sygnalizując czytelnikowi różnicę $\mathrm{w}$ ich mniemaniu między autorytaryzmem, a totalitaryzmem, posługując się pojęciem limitowanego pluralizmu. Trudności $\mathrm{w}$ przeniesieniu heglowskiej perspektywy Schmitta na grunt polskiej myśli politycznej podparte są argumentami: warcholstwa polskiej klasy politycznej, niezgodnego z prawicowoheglowską tradycją "pruskiego" rozumowania państwa oraz wadliwego procesu tworzenia obecnej Konstytucji RP, sformułowanej przez przedstawicieli zbliżonych środowisk ideologicznych, w związku z powyższym od 2007 r. unaoczniły się problemy rządu kohabitacyjnego PO z ówczesnym Prezydentem Lechem Kaczyńskim. Z kolei dr Karol Dobrzeniecki patrzy na problem impasu konstytucyjnego ze Schmittowskiej perspektywy odróżnienia konstytucji od uchwał konstytucyjnych. W dużym skrócie myślowym niemiecki prawnik legitymizuje zmiany uchwał w celu obrony nadrzędnych wartości zawartych w ,jądrze" konstytucji, takich jak - demokracja, państwo prawa, republikańska forma rządów ${ }^{7}$. Dyskusja kończy się rozważaniami prof. Wielomskiego dotyczącymi fazy narodzin mitu politycznego podnosząc, iż warunkiem koniecznym do jego powstania jest zdolność do wykrzesania agresji. Tak jak wspominałem, podjęte powyżej wątki nie wyczerpują problematyki poruszanej $\mathrm{w}$ recenzowanej dyskusji, nie obejmują chociażby związku Maxa Webera z Carlem Schmittem, czy też pojęcia „stanu wyjątkowego".

\footnotetext{
${ }^{6}$ Ibidem, s. 69-70.

7 Ibidem, s. 78.
}

Celem opracowania, będącego czwartą częścią składową recenzowanej pracy zbiorowej, zatytułowanego Neokantowski świat wartości Gustava Radbrucha jest wg jego autora prof. Jerzego Zajadło - próba odpowiedzi na pytanie: „czy neokantyzm wpłynął w jakiś zasadniczy sposób na rozwój < prawniczej> filozofii prawa"? Roboczą hipotezą badacza jest stwierdzenie, iż neokantyzm dostarczył prawnikom pięć instrumentów m.in. metodę transcedentalną wykorzystywaną poza obszarem badań przyrodniczych oraz dualizm i rozdział sfery bytu od powinności. Choć w tytule opracowania widnieje jedynie Gustav Radbruch, autor odnosi się również do dorobku Hansa Kelsena i Rudolfa Stammlera. Profesor podkreśla, iż cały dorobek pierwszego, z wyżej wymienionych ma znaczenie historyczne i poglądy te nie powinny być nadinterpretowane, odzierając je z ówczesnych realiów. Kolejno za tytułową sentencją o „świecie wartości” stoi katalogizacja Radbrucha do jednej z dwóch odmian neokantyzmu - szkoły badeńskiej, która w przeciwieństwie do szkoły marburskiej uwzględniała problematykę aksjologiczną. Za Marią Szyszkowską wyróżnia trzecią odmianę - relatywistyczną, która swoją pełnię osiągnęła w filozofii Radbrucha. Samo prawo, według tej teorii należy do świata kultury, uwzględnia również dualizm bytu od powinności, dodając jednakowoż charakterystyczny dla neokantyzmu badeńskiego aspekt aksjologiczny. Kolejno staje na Weberowskim stanowisku relatywistycznym, odnoszącym się do wartości i sądów nad nimi. Wyróżnienie świata kultury i umiejscowienie w nim prawa skutkuje wg autora faktem, iż centralnym problemem filozofii prawa staje się system wartości i wartościowania. Widać to $\mathrm{w}$ przytoczo- 
nym przykładzie immanetnego związku między prawem i sprawiedliwością „Prawo może być niesprawiedliwe, ale prawem jest tylko wówczas, gdy jego sensem jest bycie sprawiedliwym"8. Powiązanie filozofii prawa $\mathrm{z}$ nauką o słusznym prawie rodzi wg prof. Zajadło problem związany z operowaniem kategorią idei prawa, która nie istnieje w problematyce szkoły badeńskiej. Sam termin ma również rodowód heglowski, a nie kantowski. Końcową refleksją dotyczacą filozofii prawa Radbrucha jest stwierdzenie, iż pojęcie prawa można skonstruować jedynie na drodze dedukcji.

W części piątej, zatytułowanej Republika Federalna Niemiec w oczach Carla Schmitta Glosa o rzekomym oportunizmie $i$ koniunkturalizmie politycznym prof. Adam Wielomski wraca ponownie do postaci Carla Schmitta, skupiając się na obaleniu teorii o oportunistycznym charakterze jego przystąpienia do NSDAP w 1933 r. Opracowanie składa się z 9 części. Pierwsza zatytułowana Cel badawczy tekstu została podsumowana poprzedzającym zdaniem, w związku z czym należy przejść do części drugiej pt. $W$ сіепiu Norymbergi. Autor zawarł w jej ramach, krótką notę biograficzną Schmitta, odnoszącą się do wczesnych lat powojennych. Z tekstu dowiedzieć się można, że prawnik w latach 1945-1947 przebywał głównie w jak to sam określił- ,amerykańskich obozach koncentracyjnych na terenie Niemiec". Kolejne próby postawienia go przez żydowskich przedstawicieli do odpowiedzialności przed Trybunałem w Norymberdze spotęgowały u niego postawę antysemicką. Pomimo uniewinnienia, aż do 1991 r. opinia publiczna nie poznała jego

8 Ibidem, s. 98. faktycznego stosunku do samej idei sądzenia Niemców przez międzynarodowy trybunał. Z notatek wynika, iż podstawowym błędem Trybunału, było niezastosowanie się do paremii prawniczej - nullum crimen sine lege, poprzez posłużenie się pojęciem zbrodni przeciwko ludzkości, gdzie w ówczesnym prawodawstwie międzynarodowym nie określono pojęcia „ludzkość”. Kolejno, część trzecia - Powojenna <reductio ad Hitlerum $>$ opisuje powojenne traktowanie Schmitta przez społeczeństwo RFN, odsuwające go na margines społeczny w obawie przed wyimaginowaną indoktrynacją młodego pokolenia. Ukazanie cech podzielanych zarówno przez Hitlera i Schmitta tj. antykomunizm, antyliberalizm, czy też antysemityzm nazwano szerzej, opisanym w tekście zjawiskiem reductio (odnosi się również do cech zbieżnych Hitlera z innymi Niemcami, na potrzeby tekstu zestawiono postać Schmitta). W części czwartej, zatytułowanej Czy RFN jest państwem niemieckim dokonuje jednoznacznej odpowiedzi przeczącej, argumentując ją zewnętrznymi źródłami w konstytuowaniu się RFN. Rozwinięcie tej tezy znajduje się w części kolejnej, zatytułowanej Dlaczego RFN nie jest państwem niemieckim. Utożsamiana ze Schmittem logika prawicowo-heglowska, wyraża ducha obiektywnego. Zgodnie z którym, wola ludu, choćby okazała się w przyszłości błędna było wyrazem samostanowienia. Zakładając tę retorykę, ostatnim stricte państwowym tworem w Niemczech była III Rzesza, która pomimo antydemokratycznego charakteru była przejawem ducha obiektywnego społeczeństwa. Autor zestawił ten pogląd $\mathrm{z}$ teorią Kelsena, zgodnie z którą - antydemokratyczność III Rzeszy negowała ten twór jak państwo. 
Część szósta Tyrania liberalnych wartości dotyka problemu arbitralności wartości zapisanych w powojennej Konstytucji RFN. Tyrania liberalizmu uzewnętrznia się zdaniem autora tekstu w sytuacji niepodzielania przez daną jednostkę, powszechnie obowiązujących liberalnych wartości, takich jak: prawa człowieka czy demokracja. Kolejno, część siódma Niemieckossć III Rzeszy stanowi uzupełnienie poruszanych już wcześniej rozważań dotyczących legalności i obecności ducha obiektywnego w III Rzeszy. Część ósma Leyenda negra Carla Schmitta upatruje przyczyn powojennego ostracyzmu społecznego Schmitta w paru czynnikach: rosnącym od lat $30 \mathrm{XX}$ w. antysemityzmie oraz niepoddaniu się denazyfikacji. Przyczyny te sprawiły, że Schmitt stał się persona non grata w powojennym środowisku akademickim, a interpretacja jego dzieł została obarczona jego niechlubną historią w NSDAP. Naukowcy spersonifikowali idee prawne III Rzeszy z osobą C. Schmitta, nie zauważając m.in. antyhitlerowskich elementów koncepcji decyzjonizmu. Koronnym zarzutem oskarżycieli jest jednak utorowanie drogi totalitaryzmowi, przez stworzoną przez Niemca teorię państwa autorytarnego, posługującego się 48 art. konstytucji weimarskiej (dająca Prezydentowi możliwość wydawania wiążących dyrektyw). Podsumowanie problemu karierorowiczostwa i oportunizmu stanowi podsumowanie argumentów, obalających teorię o oportunizmie Schmitta, w jego prawicowo-heglowskiej ideologii, której pozostał wierny do śmierci, ostatnim stricte niemieckim państwem pozostała III Rzesza.

Autorem ostatniego opracowania, zatytułowanego Herman Heller, Carl Schmitt $i$ autoritaren Liberalismus jest mgr Kamil
Jesiołowski. Cel badawczy tekstu został sprecyzowany we Wstępie i polega na zestawieniu myśli gospodarczo-politycznej Hermana Hellera i Carla Schmitta. Zdrowa gospodarka wedtug Carla Schmitta stanowi część poświęconą, nieporuszanej wcześniej myśli gospodarczej Schmitta, autor na potrzeby opracowania analizuje treść referatu Starker Staat und gesunde Wirtschaft. Symboliczny jest fakt, iż myśl polityczna i prawna Schmitta znajduje się w opozycji do liberalizmu, tak studiując jego poglądy gospodarcze można zauważyć wiele podobieństw z myślą liberalną. Jednakowoż dla niemieckiego prawnika sfera gospodarcza, polityczna, kulturowa czy prawna nie mają charakteru autonomicznego - składają się wszystkie na jeden porządek państwowy. Analizując system Republiki Weimarskiej twierdzi, iż upolitycznienie wszystkich sfer życia, składających się na porządek państwowy skutkuje słabością danego państwa, które musi zaspokajać potrzeby wszelkich, nawet antagonistycznych grup nacisku. $\mathrm{Za}$ głównego winowajcę takiego stanu rzeczy uważa partie polityczne, którym przypisuje charakter totalitarny. Remedium na tę sytuację widzi w odgórnej (zaznacza to w tekście kilka razy) deetatyzacji państwa. Z kolei, odnosząc się do reform gospodarczych postuluje system trójelementowy: składający się z domeny prywatnej, państwowej oraz czynnika pośredniego - samorządu. System ten miałby ograniczyć dotychczasową wszechwładzę państwa, które jawi się jako władza suwerenna, fiskus czy akcjonariusz, pozostając obecna we wszystkich elementach życia gospodarczego. Za uzdrowienie systemu politycznego miałaby odpowiadać zaś druga izba parlamentu niewybieralna w wyborach powszechnych, 
ciesząca się autorytetem i realizująca rację stanu. Część trzecia pt. Autorytarny liberalizm a Sozialer Rechstaat stanowi polemiczną odpowiedź Hellera na zaproponowane przez Schmitta liberalno-autorytarne postulaty reform. Jako przejaw liberalizmu postrzega oddzielenie państwa od sfery gospodarczej, autorytaryzmu zaś w koncepcji decyzjonizmu, zawartego w artykule 48 konstytucji weimarskiej. Zestawia tę koncepcję z państwem socjalnym, gdzie za warunek konieczny poprawnego funkcjonowania takiego systemu określił - uznanie roszczeń socjalnych, ekonomicznych i politycznych proletariatu oraz stworzenie warunków ekonomiczno-socjalnej jednolitości społecznej. Opracowanie kończy się wnioskami oraz zestawieniem różnic ideologicznych analizowanych badaczy. Tekst stanowi niewątpliwie najlepszy przykład występowania wewnętrznych sprzeczności ideologicznych u Carla Schmitta. Sam postulowany bez Hellera model państwa socjalnego odnajdziemy w obecnej Ustawie Zasadniczej Republiki Federalnej Niemiec.

O holistycznycm podejściu w tworzeniu tej pracy zbiorowej może świadczyć fakt, iż wykorzytano blisko 300 źródeł (monografii, artykułów, prac zbiorowych). W skład których wchodzą pozycje literatury polskiej, angielskiej, niemieckiej, hisz- pańskiej i francuskiej. Za poszczególne wykłady i opracowania odpowiadają badacze, którzy poruszali tę tematykę w swoich dotychczasowych pracach - Adam Wielomski, Carl Schmitt a Konstytucja Rzeczypospolitej Polskiej: studium przypadku ratyfikacji traktatu Lizbońskiego - rola Prezydenta $R P^{9}, W$ poszukiwaniu Katechona. Teologia polityczna Carla Schmitta ${ }^{10}$, Katolik-Prusak-Nazista. Sekularyzacja $w$ biografii ideowej Carla Schmitta11, Jerzy Zajadło Po co prawnikom filozofia prawa? ${ }^{12}$. Opracowanie zawiera wyselekcjonowane treści, które zostały uporządkowane w kolejności, pozwalającej czytelnikowi zrozumienie kolejnych części pracy. Pozycja rzuca nowe światło na polski impas konstytucyjny, zestawiając rodzimy problem $\mathrm{z}$ mechanizmami koncepcyjnymi opracowanymi przez niemieckich uczonych I połowy XX wieku.

${ }_{9}$ P. Bała, A. Wielomski, Carl Schmitt a Konstytucja Rzeczypospolitej Polskiej, Klub Zachowawczo-Monarchistyczny, Warszawa 2008.

${ }^{10}$ A. Wielomski, W poszukiwaniu Katechona. Teologia polityczna Carla Schmitta, Wydawnictwo Von Borowiecky, 2017.

11 A. Wielomski, Katolik-Prusak-Nazista. Sekularyzacja w biografii ideowej Carla Schmitta, Wydawnictwo Von Borowiecky, 2019.

12 J. Zajadło, Po co prawnikom filozofia prawa?, Wolters Kluwer Polska, Warszawa-Kraków 2008. 